\title{
Effect of saponins of Quillaja saponaria extracts in combination with Pseudomonas protegens to control Gaeumannomyces graminis var. tritici in wheat
}

\author{
Jonathan A. González-Castillo ${ }^{1}$, Tamara P. Quezada-D’Angelo ${ }^{1}$, Gonzalo I. Silva-Aguayo ${ }^{1}$, \\ and Ernesto A. Moya-Elizondo ${ }^{1^{*}}$
}

${ }^{1}$ Universidad de Concepción, Facultad de Agronomía, Av. Vicente Méndez 595, Chillán, Chile. *Corresponding author (emoya@udec.cl).

Received: 21 March 2018; Accepted: 19 June 2018; doi:10.4067/S0718-58392018000300378

\begin{abstract}
Extracts rich in saponins from Quillaja saponaria Mol. and populations of rhizobacteria from the genus Pseudomonas, which produce antimicrobial compounds, have been associated with reduction of the fungus Gaeumannomyces graminis var. tritici, the causal agent of take-all disease, which is responsible for severe loss of wheat (Triticum aestivum L.) crops worldwide. However, there is a limited background on the interaction between these bacteria and natural triterpenoids. The aim of this research was to assess the effect of saponin rich extract on Pseudomonas protegens strains 2,4-diacetylphloroglucinol-producers under in vitro and in plant conditions and determining the synergistic effect to be used together to control G. graminis var. tritici in wheat plants. We determined that $8 \%$ and $90 \%$ of saponins rich $Q$. saponaria extracts have a differential effect on $P$. protegens according to their purity $(\mathrm{P} \leq 0.05)$. On wheat seedlings, quillaja extract with $90 \%$ of saponins did not affect the three antagonistic bacterial strain populations assessed, but affected biofilm formation at saponins concentration of $7360 \mathrm{mg} \mathrm{L}^{-1}$. Pseudomonas protegens strains had a variable antagonist activity in wheat plants, and controlled the fungus when were combined with different concentrations of pure $Q$. saponaria extract, with the concentration of $1840 \mathrm{ppm}$ reducing the take-all disease in $32.5 \%$ with respect to the control inoculated with $G$. graminis var. tritici $(\mathrm{P} \leq 0.05)$. However, no synergistic effects when the plant extract was combined with the bacterial strains were observed. These results showed the promising and complexity of combining bacterial and plant extract to develop a biopesticide, which could control this fungal disease.
\end{abstract}

Key words: Biofungicide, 2,4-DAPG, Pseudomonas protegens, Quillaja saponaria, saponins, Triticum aestivum.

\section{INTRODUCTION}

Quillay (Quillaja saponaria Mol.; Quillajaceae) is an endemic Chilean evergreen tree distributed from Valparaíso Region $\left(30^{\circ} \mathrm{S}\right.$ lat) to La Araucanía Region ( $38^{\circ} \mathrm{S}$ lat) (Schlotterbeck et al., 2015), which is rich in bidesmosidic saponins into its bark, leaves, and parts of the trunk (Donoso et al., 2011; Schlotterbeck et al., 2015). Saponins are secondary triterpenoid metabolites produced in many plant species, some with antifungal activity (Augustin et al., 2011; Ahmed et al., 2012). Various studies have shown a control effect by Q. saponaria on different species of Oidium (Apablaza et al., 2002; Moya et al., 2010), as well as on other phytopathogenic fungi such as Botrytis cinerea Pers.:Fr. (Ribera et al., 2008) and Gaeumannomyces graminis (Sacc.) Oliver and Von Arx var. tritici Walker (Apablaza and Moya, 2004). 
Take-all disease, caused by the ascomycete fungus G. graminis var. tritici (Ggt), causes severe losses in wheat (Triticum aestivum L.; Poaceae) crops in Chile (Andrade et al., 2011; Moya-Elizondo et al., 2015; Durán et al., 2017) and worldwide (Paulitz et al., 2010; Yang et al., 2011; Zhang et al., 2017). This fungus triggers rotting and decomposition of the roots, crown, and basal culm of wheat plants and other cereals (Paulitz, 2010; Paulitz et al., 2010). Decreases in plant yield are associated with plant loss during crop growth and decreased size and number of spikes, or the presence of less or shrivelled grains. Ggt normally inhabits soil and infests the vascular cylinder of the culm, reducing water and nutrient absorption, and causing white spikes during flowering, premature ripening, and plant death (Paulitz et al., 2010; Yang et al., 2017).

Despite great research efforts, a successful control of take-all disease has not yet been achieved (Paulitz et al., 2010; Vera et al., 2014; Zhang et al., 2017). The majority of cultivated wheat varieties are susceptible to this disease (Vazvani et al., 2017), therefore its management is limited to selecting less susceptible varieties, balanced fertilization, crop rotation (Mathias-Ramwell et al., 2016), and the use of seed treatments with chemical fungicides (Paulitz, 2010; Yang et al., 2014; Zhang et al., 2017). Fungicides with active ingredients such as fenbuconazole, fluquinconazole, nuarimol, silthiofam, triadimefon, triadimenol, and triticonazole have been unable to completely control take-all disease, only slowing or decreasing the infection caused by Ggt (Paulitz, 2010; Andrade et al., 2011; Vera et al., 2014).

Different microbial agents with antagonist activity against Ggt have been described (Park et al., 2011; Liu et al., 2011; Kwak et al., 2012; Yang et al., 2014; 2017; Zhang et al., 2017). Among them, bacteria from the genus Pseudomonas spp., which inhabit the wheat rhizosphere, have been studied in depth because of their control of Ggt and other pathogenic fungi that cause root rot in wheat, such as Rhizoctonia, Pythium, and Fusarium (Park et al., 2011; Mavrodi et al., 2012; Yang et al., 2014). Bacteria from the genus Pseudomonas produce metabolites with antifungal effects such as 2,4-diacetylphloroglucinol (2,4-DAPG), hydrocyanic acid, pyoluteorin, pyrrolnitrin, and phenazine derivatives (Ramette et al., 2011; Kwak et al., 2012; Yang et al., 2017). Recently, the presence of 2,4-DAPG producing Pseudomonas bacteria has been reported in fields in southern Chile (Moya-Elizondo et al., 2013; Durán et al., 2017). Bacteria that produce 2,4DAPG are a promising source for the development of seed inoculants for disease control, although this compound has high instability in the rhizosphere (Kwak et al., 2012).

Commercial use of these strains requires exhaustive research on its formulation as a biopesticide, which could require natural compounds that affect the pathogen, but also favor the growth of beneficial bacteria in the rhizosphere. Although the potential impact of $Q$. saponaria extracts on fungi such as Ggt is valuable, there is limited research evaluating the direct effect of these components on pseudomonads populations and their combined effect on the decrease of pathogenic fungi in wheat. This is important because the combined use of Pseudomonas spp. bacteria with saponinic extracts could lead to the development of a biofungicide that diminishes Ggt. The present study evaluated the bioactive effects of saponin-rich $Q$. saponaria extracts combined with strains of P.protegens on the fungi Ggt in wheat plants. We determined the in vitro effect that triterpenic extracts from $Q$. saponaria exhibit on populations of $P$. protegens. Furthermore, we compare growth of $P$. protegens populations on wheat roots treated and untreated with $Q$. saponaria extracts high in saponins, and the effect of these mixtures on the development of the take-all disease in wheat plants.

\section{MATERIALS AND METHODS}

\section{Biological material}

Two saponin-rich Q. saponaria extracts were used: a crude extract with a concentration of 8\% (w/w) of saponins (QL1000, Desert King Chile, Quilpué, Chile), and a pure extract with 90\% (w/w) of saponins (Vet Sap, Desert King Chile Ltda., Quilpué, Chile). Saponins concentrations of these extracts were determined by HPLC (San Martín and Briones, 2000).

Three strains of Pseudomonas protegens 2,4-diacetylphloroglucinol (2,4-DAPG)-producers were used: strain Pf-5 (Ramette et al., 2011) and the Chilean strains Ch-b7 and Ca-10, which had the gene phlD+ associated with production of this compound. The strain Pf-5 was gently facilitated by Dr. Brian McSpadden from Ohio State University, USA. Strains Ch-B7 and Ca-10 were isolated from wheat roots in a survey conducted in Chile between the Biobío and Los Lagos Regions in 2012 (Moya-Elizondo et al., 2013). The pathogenic isolate Oso1 of the fungus G. graminis var. tritici was obtained from English ryegrass plants (Lolium perenne L.; Poaceae) from Osorno, Chile. This fungal isolate presents high aggressiveness in wheat plants. 


\section{Bioactivity of quillay extracts on beneficial strains of Pseudomonas protegens}

Pure isolations of the three bacterial strains were seeded on Petri dishes with King's B medium, and pure colonies were obtained, which were then incubated in individual tubes with $10 \mathrm{~mL}$ of King's B medium at $24{ }^{\circ} \mathrm{C}$ under continuous agitation at $150 \mathrm{rpm}$ for 24 to $72 \mathrm{~h}$. At the end of incubation, $50 \mu \mathrm{L}$ were taken from the bacterial colonies, which were put onto ELISA microplates that contained $200 \mu \mathrm{L}$ of King's B medium at concentrations of 0, 200, 400, 800 , and $8000 \mathrm{mg} \mathrm{L}^{-1}$ of each $Q$. saponaria extract. Optical density was measured at $600 \mathrm{~nm}$ with a microplate reader (RT-2100C; Rayto, Shenzhen, P.R. China). Spectrophotometric correction controls were wells with the different concentrations of $Q$. saponaria extract plus $50 \mu \mathrm{L}$ sterile King B media without bacteria. Each concentration and control was repeated three times for each treatment, using one microplate for each extract of $Q$. saponaria. At the same time, the content of the tubes was diluted in ELISA microplates, obtaining dilutions of $10^{-4}, 10^{-5}, 10^{-6}$, and $10^{-7}$ of the bacterial suspensions in King's B medium. From these dilutions, three microdrops of $10 \mu \mathrm{L}$ were placed on a Petri dish with agar King's B medium, and these plates were incubated at $24{ }^{\circ} \mathrm{C}$ during $24 \mathrm{~h}$ to determine the initial bacteria concentration by quantifying the number of colony-forming units (CFU). Additionally, after obtaining the $24 \mathrm{~h}$-spectrophotometric reading from the bacterial populations grown in the different concentrations of extracts described above, the number of CFU was determined following the methodology previously described. This experiment was carried out in triplicate.

The direct effects of $Q$. saponaria saponins on the growth of P. protegens and on the antagonistic activity of the bacteria against Ggt were assessed. Three bacterial strains were cultivated $\left(10^{5}\right.$ initial CFU) in $1.5 \mathrm{~mL}$ tubes with different $Q$. saponaria saponin concentrations of the pure extract $\left(0,1840,4600\right.$, and $\left.9200 \mathrm{mg} \mathrm{L}^{-1}\right)$ diluted in water. One control of each strain and concentration was grown in King's B medium. All concentrations were incubated separately for 24,48 , and $72 \mathrm{~h}$. For each experimental time, and for each saponin concentration, a $10 \mu \mathrm{L}$ aliquot was taken from each bacteria population and placed on a Petri dish with potato dextrose agar (PDA) plus King's B medium, which also contained a $5 \mathrm{~mm}$ diameter plug of Ggt isolate Oso1. The fungus had been previously grown in PDA for $7 \mathrm{~d}$ at $25 \pm 1{ }^{\circ} \mathrm{C}$ in an incubation chamber. The fungus, together with the bacteria treated with different concentrations of saponins, was grown for $4 \mathrm{~d}$. Mycelial growth was measured with a ruler from the border of the slice of mycelium, to the point inoculated with bacteria. After $24 \mathrm{~h}$, the bacteria grown in different concentrations of saponins were centrifuged for $2 \mathrm{~min}$ at $3000 \mathrm{rpm}$, and the supernatant was extracted. Bacteria were then re-suspended twice in sterile distilled water (SDW) in order to subsequently quantify CFU as previously described.

In vitro activity exhibited by saponinic concentration of $Q$. saponaria extracts on antagonistic bacteria of $G$. graminis var. tritici in wheat seedlings

Wheat (Triticum aestivum L.) 'Pandora-INIA' (Instituto de Investigaciones Agropecuarias INIA, Chile) seeds were sterilized for $1.5 \mathrm{~min}$ in $0.5 \%$ sodium hypochlorite, constantly agitated, and washed six times with SDW (3 min per wash) in a laminar flow cabinet. Seeds were placed in Petri dishes on wet paper towels until they germinated. Then, seedlings were then placed in a $15 \mathrm{~cm}$ Petri dish with water-agar medium. Seedlings were grown until their roots reached $1-2 \mathrm{~cm}$. The three strains of $P$. protegens were previously grown in a tube with $10 \mathrm{~mL}$ of King's B medium at $24{ }^{\circ} \mathrm{C}$ at $48 \mathrm{~h}$. After inoculation, bacteria samples were diluted in series in Eppendorf tubes with $900 \mu \mathrm{L}$ SDW to determine the initial CFU by using the three-microdrop method described previously. The concentrations of each bacterium in a dilution of $10^{-4}$ were centrifuged at $3000 \mathrm{rpm}$ for $10 \mathrm{~min}$ to eliminate the supernatant and were resuspended in SDW. From each suspension, $200 \mu \mathrm{L}$ were taken and mixed with $800 \mu \mathrm{L}$ of the pure $90 \%$ saponins extract, at concentrations of $0,1840,4600$, and $9200 \mathrm{mg} \mathrm{L}^{-1}$ of $Q$. saponaria saponin extract. The resulting mixtures of $0,1472,3680$, and $7360 \mathrm{mg} \mathrm{L}^{-1}$ of saponins were separately placed on the roots of each wheat seedling. Three roots of each seedling were inoculated with $20 \mu \mathrm{L}$ of the mixture, and the samples were incubated at $24{ }^{\circ} \mathrm{C}$ for 24,48 , and $72 \mathrm{~h}$, respectively. After each incubation time, three $1 \mathrm{~mm}$ slices were cut from each root from the sections previously inoculated with the Pseudomonas and saponin mix. These slices were placed onto individual wells of an ELISA microplate with $100 \mu \mathrm{L}$ of King's B medium, to be incubated for $24 \mathrm{~h}$ at $24^{\circ} \mathrm{C}$. Following incubation, the samples were placed on a Petri dish with agar King's B medium to obtain the final CFU count using the three-microdrop method. Each treatment was applied three times, and each experiment was carried out in triplicate. All the in vitro trials were conducted in a completely random design. 
Bacterial growth on the roots of wheat 'Pandora-INIA' was observed under scanning electron microscopy. Seeds were sterilized and germinated according to the protocol formerly mentioned. Individual seedlings were placed on Petri dishes with agar-water medium. At the same time, $600 \mu \mathrm{L}$ bacterial suspension were diluted $10^{-4}$ and mixed with $2400 \mu \mathrm{L}$ saponin $90 \%$-rich Q. saponaria extract, arriving at a saponin concentration of $7360 \mathrm{mg} \mathrm{L}^{-1}$. The roots were individually inoculated, with $3 \mathrm{~mL}$ mixes of Pseudomonas and $Q$. saponaria. Additionally, one treatment was prepared with only bacteria, as well as a control with only SDW. Petri plates were kept in constant agitation for $24 \mathrm{~h}$ and later left to incubate at $24{ }^{\circ} \mathrm{C}$ for $24 \mathrm{~h}$. Tubes containing the slices of treated roots were prepared in triplicate and incubated for $5 \mathrm{~d}$. They were then fixed in $2.5 \% 0.1 \mathrm{M}$ glutaraldehyde phosphate buffer $(\mathrm{pH} 7.2)$ for $1 \mathrm{~h}$ at $4{ }^{\circ} \mathrm{C}$, and then fixed in $1 \%$ osmium tetroxide buffer for $1 \mathrm{~h}$. Samples were dehydrated in a series of ethyl alcohol washings, followed by two changes of propylene oxide until reaching a critical drying point and then covered with gold particles. Sections were examined under a scanning electron microscope (SEM) (JEOL JSM-6380 LV, JEOL USA, Peabody, Massachusetts, USA) in the Advanced Microscopy Centre at the Universidad de Concepción, Chile.

\section{Control activity by mix of saponinic concentration of $Q$. saponaria extracts and antagonist bacteria on $G$. graminis var. tritici in wheat plants.}

Individual PVC pots of $28 \mathrm{~mm}$ diameter and $200 \mathrm{~mm}$ depth were filled with $180 \mathrm{~g}$ of an Andisol soil (Humic Haploxerands; Soil Survey Staff, 2014) that had been sized ( $2 \mathrm{~mm}$ grain size), sterilized, and inoculated. Two oat grains infested with Ggt isolate Oso1 were placed at $10 \mathrm{~cm}$ and $5 \mathrm{~cm}$ under the upper surface of the pot into the soil substrate. Each pot was seeded with one previously germinated 'Pandora-INIA' seed at $1.5 \mathrm{~cm}$ depth. The pre-germinated seeds were inoculated separately with the three bacterial strains diluted at $0,1840,4600$, and $9600 \mathrm{mg} \mathrm{L}^{-1}$ saponins from the $90 \%$ saponins extract. These treatments were applied to the pre-germinated seeds, being inoculated with $500 \mu \mathrm{L}$ of an individual suspension of $10^{-8} \mathrm{CFU}$ per $\mathrm{mL}$ of each strain (grown in the conditions previously reported) plus $100 \mu \mathrm{L}$ of the different triterpenic extract concentrations from Q. saponaria saponins. Ggt inoculated and non-inoculated controls were considered, and they were treated with $600 \mu \mathrm{L}$ SDW. An additional control inoculated with Ggt was treated only with a saponin concentration of $9200 \mathrm{mg} \mathrm{L}^{-1}$ from de pure extract of $Q$. saponaria with $90 \%$ saponins, receiving $500 \mu \mathrm{L} \mathrm{SDW}$ in replacement of the bacteria. All treated pots were kept in a plant growing room under controlled temperature conditions of $22 \pm 2{ }^{\circ} \mathrm{C}$ and a $14: 10 \mathrm{~h}$ photoperiod $(68.0$ to $88.3 \mu \mathrm{mol}$ $\mathrm{m}^{-2} \mathrm{~s}^{-1}$ ) with LED lights: red 630-660 nm, yellow $615 \mathrm{~nm}$, and blue $460-490 \mathrm{~nm}$. In total, each treatment was repeated six times, considering one pot as an experimental unit. Pots were watered three times per week and fertilized every 2 wk with 5 $\mathrm{mL}$ of commercial nutrient solution (12\% N; $4 \%$ P; $7 \%$ K, Best Garden, Comercial VOS S.A., Colina, Chile) for each pot. This experiment was carried out in triplicate and all the trials were conducted in a completely random design.

Plants were grown for $45 \mathrm{~d}$, and subsequently, roots of each plant were evaluated for level of infection, according to a Ggt damage index proposed by Freeman et al. (2005), in which $0=$ no infected roots; $1=$ up to $10 \%$ infected roots, $2=11 \%-25 \%$ infected roots, $3=26 \%-50 \%$ infected roots, $4=51 \%-75 \%$ infected roots, and $5=76 \%-100 \%$ infected roots. Additionally, the average of the values obtained from the damage index for the three bacterial strains assessed were used to calculate a the take-all index $(\mathrm{TAI})$ for each treatment, by using the following formula: TAI $=[(0 \times \mathrm{nr}$ plants value 0$)+(10 \times \mathrm{nr}$ plants value 1$)+(25 \times$ nr plants value 2$)+(50 \times \mathrm{nr}$ plants value 3$)+(75 \times$ nr plants value 4$)$ $+(100 \times$ nr plants value 5$)] /$ Total number of plants. These data were analyzed to determine average differences among treatments and considered a randomized block design, where the bacterial strain was a block.

\section{Data analysis}

Data were analyzed in the normality of their distributions by the Shapiro-Wilk test. Data that did not present normal distribution were logarithmically transformed. The $\mathrm{F}$ test was used to determine the differences between each of the experiment replicates. If no differences were obtained $(\mathrm{p} \leq 0.05)$, data obtained from each experiment replicate were averaged and analyzed; if differences were observed between experiments, they were separately analyzed. In the in vitro and in vivo experiments, ANOVA was used to analyze effects of the saponinic extracts on Pseudomonas and control the activity that the mix of the bacteria with the concentration of the extract had on Ggt and the disease expression. Tukey multiple comparison test was used to determine differences among means of the treatments ( $\leq 0.05)$. Qualitative and transformed data that did not show normality in their distributions were analyzed with the non-parametric Kruskal-Wallis test. All statistical analyses were performed with the program InfoStat version 2015 (Grupo InfoStat, Facultad de Ciencias Agropecuarias, Universidad Nacional de Córdoba, Argentina). 


\section{RESULTS}

\section{Bioactivity of $Q$. saponaria extracts on beneficial strains of Pseudomonas protegens}

The average results of bacterial count after $24 \mathrm{~h}$ of growth showed significant differences between the concentrations for both $Q$. saponaria extracts $(\mathrm{P} \leq 0.05)$, but not between the bacterial strains (Figure 1). Bacterial growth of the strains was similar among concentrations of 0 and $800 \mathrm{mg} \mathrm{L}^{-1}$ of saponins, while the $8000 \mathrm{mg} \mathrm{L}^{-1}$ saponins from the extract with $90 \%$ of saponins reduced CFUs and absorbance values in $36 \%$ and $16.2 \%$, respectively. At $8000 \mathrm{mg} \mathrm{L}^{-1}$ saponins no live colonies were isolated from the crude extract with $8 \%$ of saponins (Figure 1). It is important to note that at 8000 $\mathrm{mg} \mathrm{L}^{-1}$ saponin of the $8 \%$ saponins extract, precipitate was produced in the bottom of the microplate wells, meaning that absorbance readings were invalid.

On average, the pure $90 \%$ saponins extract from $Q$. saponaria significantly reduced bacterial growth of $P$. protegens at $63 \%$ when grown at $1840 \mathrm{mg} \mathrm{L}^{-1}$ saponins during $24 \mathrm{~h}$ with respect to the control (King's B medium). Nevertheless, this decrease in bacterial growth was lower in comparison to the treatment with bacteria grown only in SDW $\left(0 \mathrm{mg} \mathrm{L}^{-1}\right)$, in which the bacteria population decreased $78.3 \%$ (Table 1). However, when the strains were analyzed individually, this decreasing behavior was only observed in the strain Ch-B7, given that the other two showed that the addition of saponins from Q. saponaria did not affect the population growth of the antagonist bacteria $\left(77.8 \%\right.$ for $0 \mathrm{mg} \mathrm{L}^{-1} ; 57.3 \%$ for $1840 \mathrm{mg} \mathrm{L}^{-1}$; $49.7 \%$ for $4600 \mathrm{mg} \mathrm{L}^{-1}$; $27.9 \%$ for $9200 \mathrm{mg} \mathrm{L}^{-1}$ ) (Table 1). When comparing bacterial growth in the

Figure 1. Average Pseudomonas protegens colony-forming units (CFUs) expressed in log base after $24 \mathrm{~h}$ incubation in King's B medium supplemented with different saponin concentrations from two Quillaja saponaria extracts: a pure extract with $90 \%$ saponins and a crude extract with $8 \%$ of saponins.

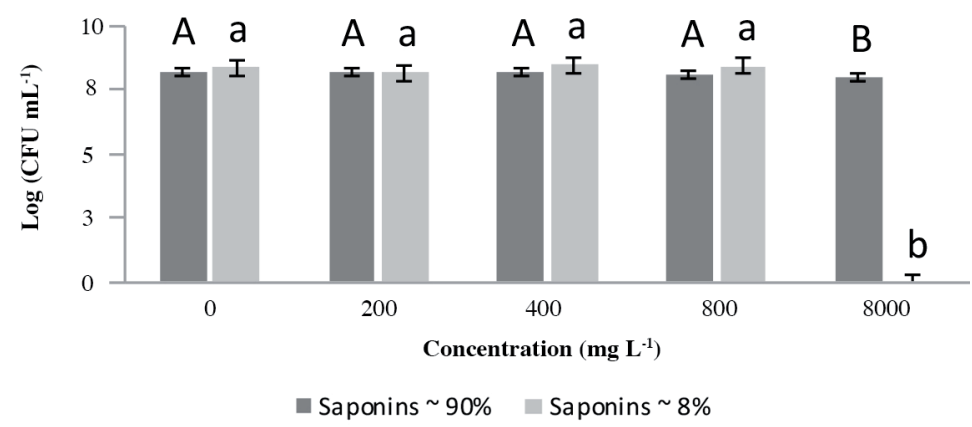

Different letters on the bars of each extract show significant differences among doses, according to the Tukey multiple comparison test $(\mathrm{P} \leq 0.05)$. Data are expressed as mean \pm MSD of three experiments.

Table 1. Bacterial colony-forming units $\left(\log \mathrm{CFU} \mathrm{mL}^{-1}\right)$ of the three Pseudomonas protegens strains grown in different concentrations of Quillaja saponaria extract with $90 \%$ saponins.

\begin{tabular}{lccccc}
\hline & \multicolumn{3}{c}{ Pseudomonas protegens strains } & & \\
\cline { 2 - 3 } & Pf-5 & Ch-B7 & Ca-10 & Mean & $\begin{array}{c}\text { Decrease } \\
\text { percentage }\end{array}$ \\
\hline Treatments $^{1}$ & & & & & $\%$ \\
0 & $6.2 \mathrm{a}$ & $5.9 \mathrm{~b}$ & $6.1 \mathrm{a}$ & $6.1 \mathrm{~b}$ & $78.3 \%$ \\
1840 & $6.7 \mathrm{a}$ & $6.2 \mathrm{~b}$ & $6.2 \mathrm{a}$ & $6.4 \mathrm{~b}$ & $63.0 \%$ \\
4600 & $6.7 \mathrm{a}$ & $6.5 \mathrm{ab}$ & $6.3 \mathrm{a}$ & $6.5 \mathrm{ab}$ & $48.1 \%$ \\
9200 & $6.5 \mathrm{a}$ & $6.6 \mathrm{ab}$ & $6.1 \mathrm{a}$ & $6.4 \mathrm{ab}$ & $30.2 \%$ \\
Control $^{2}$ & $6.9 \mathrm{a}$ & $6.8 \mathrm{a}$ & $6.8 \mathrm{a}$ & $6.8 \mathrm{a}$ & - \\
P-Value $^{-1}$ & 0.397 & 0.016 & 0.274 & 0.003 & \\
\hline
\end{tabular}

Means of each treatment were compared with the control grown in King's B medium to obtain the reduction percentage in CFU.

Different letters in columns show significant differences between treatments for each bacterial strain, according to the Tukey multiple comparison test $(\mathrm{P} \leq 0.05)$.

${ }^{1}$ Values expressed in $\mathrm{mg} \mathrm{L}^{-1}$ saponins obtained from the pure extract of Quillaja saponaria with $90 \% \mathrm{w} / \mathrm{w}$ of saponins.

${ }^{2}$ Control considering bacterial growth obtained in King' B medium. 
different concentrations of saponin extracts $\left(0,1840,4600\right.$, and $\left.9600 \mathrm{mg} \mathrm{L}^{-1}\right)$ in the different evaluation moments (24, 48 , and $72 \mathrm{~h}$ ), a decrease was observed in bacterial count for all concentrations with respect to the initial CFU count of $1.7 \times 10^{-6}$ (Figure 2). This decrease was marked at $24 \mathrm{~h}$, stabilized at $48 \mathrm{~h}$, and maintained constant at $72 \mathrm{~h}$, without observing significant differences among times or concentrations of $Q$. saponaria saponins $(\mathrm{P}>0.05)$. Although a more linear decrease was observed at 4600 and $9200 \mathrm{mg} \mathrm{L}^{-1}$ saponin, the treatment without saponins and also with the lowest concentration $\left(1840 \mathrm{mg} \mathrm{L}^{-1}\right.$ ) presented a more marked decline in bacterial growth (Figure 2). Moreover, decreasing control activity by P. protegens on Ggt was not observed in the assays carried out in vitro after the bacteria was grown during $24 \mathrm{~h}$ in different saponin concentrations of the Q. saponaria extract with $90 \%$ of saponins (Figure 3). The bacteria maintained their antagonistic activity as collected bacteria obtained from the tubes with different concentrations of saponins were able to detain the mycelial growth of the fungus around 5 to $7 \mathrm{~mm}$ before entering in contact with the bacterial colony.

\section{In vitro activity of saponins from $Q$. saponaria on beneficial bacteria in seedling wheat roots}

The time elapsed between the three replicates of the experiments did not influence treatment response (P-value $>0.05$ ). For this reason, the three experiments were used as the same dataset for analysis of each evaluation period $(24,48$, and $72 \mathrm{~h})$ and bacterial strain (Pf-5, Ca-10, and Ch-B7). The 90\% saponins extract applied to the root did not present antagonistic activity on the growth of $P$. protegens populations in any of the four concentrations assessed. However, the bacterial count was variable between the strains at different concentrations and evaluation times, when the bacterial strains were inoculated on the wheat roots $(\mathrm{p}<0.05)$. The roots that were not treated with the saponin-rich extract did not present

Figure 2. Average colony-forming units (CFUs) expressed in log base for different Pseudomonas protegens strains grown in different saponins concentrations obtained from Quillaja saponaria extract with $90 \%$ saponins at three different inoculation times.

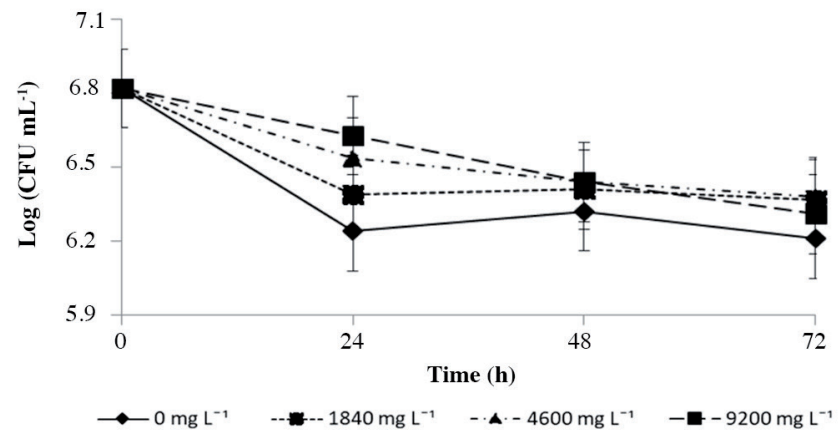

Data are expressed as mean \pm standard error.

Figure 3. Inhibition of Pseudomonas protegens on Gaeumannomyces graminis var. tritici under in vitro conditions for the strains Pf-5 (a), Ch B-7 (b), and Ca-10 (c) after 4 d incubation on a PDA-King's B medium observed for bacterial population previously grown during $24 \mathrm{~h}$ in different saponins concentrations from a pure Quillaja saponaria extracts with $90 \%$ saponins, where $0 \%=0 \mathrm{mg} \mathrm{L}^{-1}, 0.2 \%=1472 \mathrm{mg} \mathrm{L}^{-1}, 0.5 \%=3680 \mathrm{mg} \mathrm{L}^{-1}$, and $1 \%=7360 \mathrm{mg} \mathrm{L}^{-1} \mathrm{saponins}$.

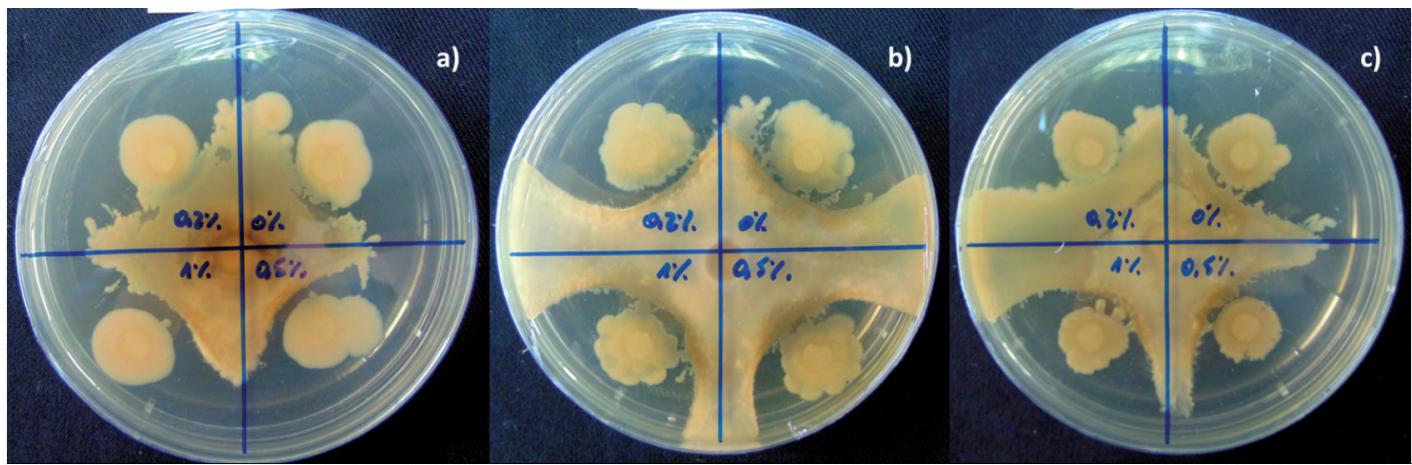


significant differences in CFU for any of the three bacteria during the evaluation periods. Pseudomonas protegens strain Pf-5 at a $7360 \mathrm{mg} \mathrm{L}^{-1}$ saponin showed a significantly lower CFU population at $24 \mathrm{~h}$ than at $72 \mathrm{~h}$, while the bacterial population observed at $48 \mathrm{~h}$ was not different in comparison to those observed at 24 and $72 \mathrm{~h}$ (Figure 4a). The reduction of CFU observed at $24 \mathrm{~h}$ was $35.4 \%$ less than the initial measurement $(0 \mathrm{~h})$, and at the same time was surpassed up to $102 \%$ at $72 \mathrm{~h}$. Strain Pf-5, at $3680 \mathrm{mg} \mathrm{L}^{-1}$ saponins, slightly decreased at $24 \mathrm{~h}(8.7 \%)$ and arrived at a reduction of $39.5 \%$ in the bacterial population observed at $48 \mathrm{~h}$ in comparison to the initial measurement at $0 \mathrm{~h}$. Nonetheless, the bacterial growth was recovered at $72 \mathrm{~h}$ after inoculation on the root (Figure $4 \mathrm{~b}$ ).

Bacterial strain Ca-10 showed an increase in bacterial counts at $72 \mathrm{~h}$ in a $1472 \mathrm{mg} \mathrm{L}^{-1}$ semi-pure Q. saponaria saponin extract concentration, reaching $64.7 \%$ more than $\mathrm{CFU}$ with respect to measurements made at 24 and $48 \mathrm{~h}$ (Figure 4c), which were similar to initial CFU measurements used to inoculate roots $\left(2.14 \times 10^{-7} \mathrm{CFU}\right)$. Meanwhile, the strain Ch-B7 showed no differences between the three time periods in any of the $Q$. saponaria concentrations evaluated. Scanning electron microscopy showed that $P$. protegens strains settled when inoculated on root surfaces of wheat for $24 \mathrm{~h}$ (Figure 5). However, when these bacteria were applied without $Q$. saponaria extracts, a more compact and dense bacteria population was observed, forming biofilm that grouped them together (Figure 5b). On the other hand, combining bacteria with saponin rich extracts from the Q. saponaria strain resulted in a decline in bacteria populations, with lesser compaction on root surfaces, which is associated with less aggregation of bacteria under a biofilm (Figure 5c).

Figure 4. Average colony-forming units (CFUs) expressed in log base for various strains of Pseudomonas protegens inoculated on wheat roots mixed with pure extracts of Quillaja saponaria with $90 \%$ saponins at three different times from inoculation. Strain Pf-5 populations at $Q$. saponaria saponin concentrations of $7360 \mathrm{mg} \mathrm{L}^{-1}(\mathrm{a}), 3680 \mathrm{mg} \mathrm{L}^{-1}$ (b), and strain Ca-10 at $1472 \mathrm{mg} \mathrm{L}^{-1}(\mathrm{c})$.

a)

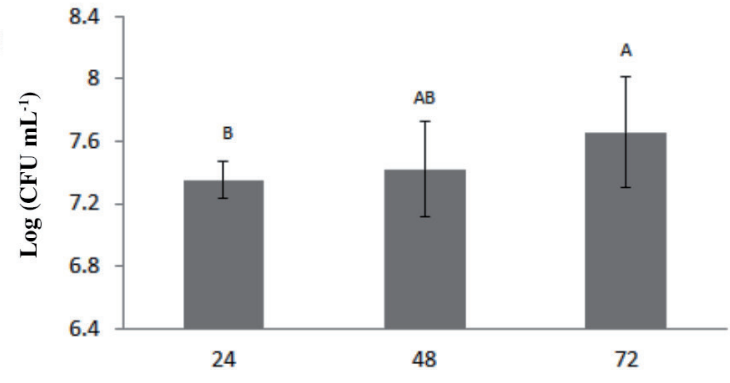

b)

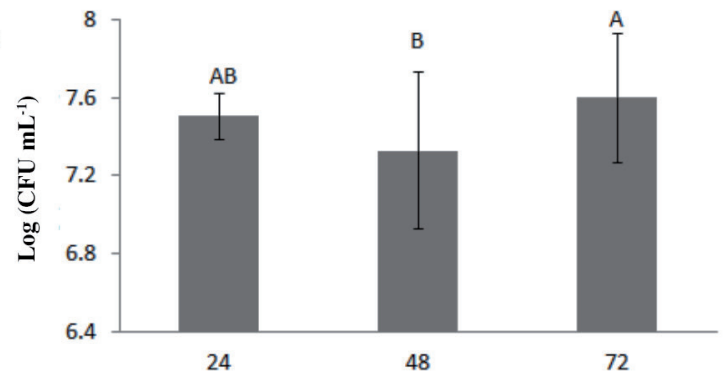

c)

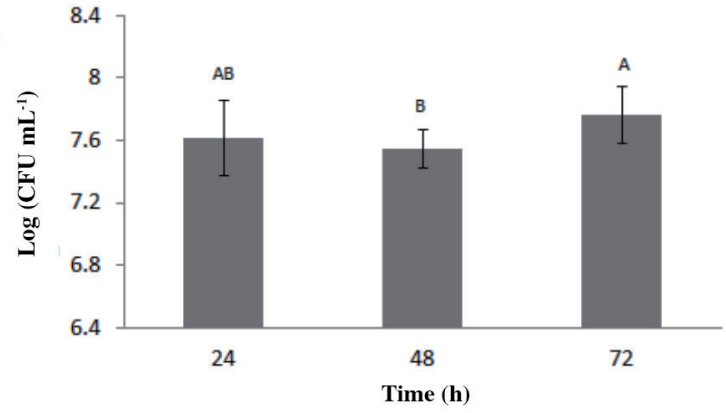

Different letters on the bars show significant differences according to the Tukey multiple comparison test $(\mathrm{P} \leq 0.05)$.

Data are expressed as mean \pm standard deviation. 
Figure 5. Observations through scanning electron microscopy for wheat root surfaces without inoculation (a), inoculated only with Pseudomonas protegens (b) and wheat roots treated with bacteria in combination with $7360 \mathrm{mg} \mathrm{L}^{-1} \mathrm{saponins}$ from Quillaja saponaria (c), after $24 \mathrm{~h}$.
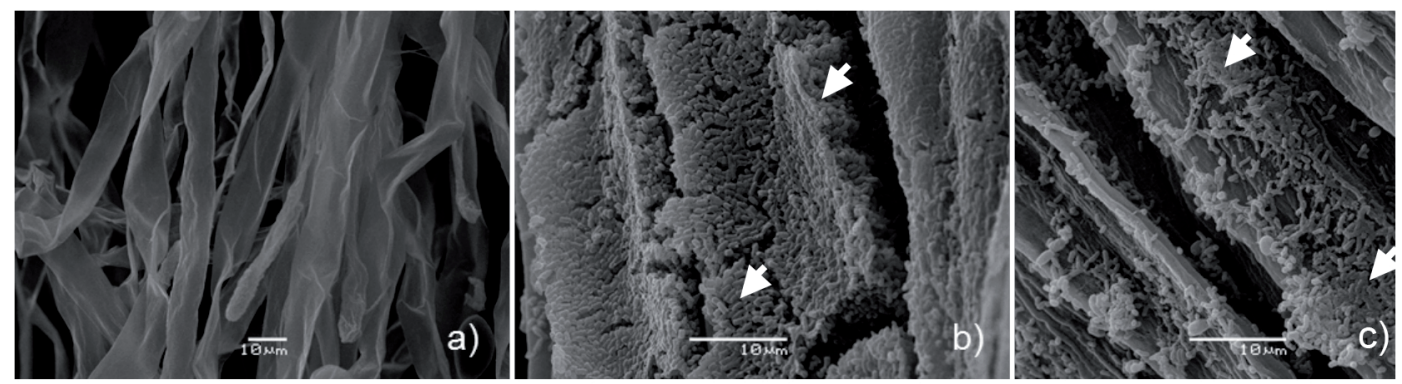

Arrows indicate aggregation of bacteria and biofilm formation.

In vivo effect of saponin extract in combination with antagonistic bacteria on the disease caused by G. graminis var. tritici in wheat plants.

When analyzing the damage index of Ggt on wheat plants inoculated with different $P$. protegens strains mixed with different $Q$. saponaria extract concentrations $\left(0,1840,4600\right.$, and $\left.9200 \mathrm{mg} \mathrm{L}^{-1}\right)$, significant differences were observed for each bacterial strain $(\mathrm{P}<0.05)$. Moreover, all inoculated treatments were infested by the fungus and presented damages significantly different than the treatment non-inoculated with the pathogenic fungus. The bacterial strain Pf-5 did not show differences on damage caused by G. graminis var. tritici when this bacterium was combined with the different saponin concentrations. The same occurred for treatment where wheat plants were only inoculated with a $9200 \mathrm{mg} \mathrm{L}^{-1}$ saponin concentration. The strain Ca-10 presented a reduction of the damage index with respect to treatment inoculated only with the fungus, when this bacterium was used alone or in combination with the three different saponins concentrations derived from Q. saponaria $\left(1840,4600\right.$, and $\left.9200 \mathrm{mg} \mathrm{L}^{-1}\right)(\mathrm{P}<0.05)$ (Figure 6a). Strain Ch-B7 had a significant decrease in damage caused by fungus on the wheat plants when this bacterium was combined with 1840 and $4600 \mathrm{mg} \mathrm{L}^{-1} Q$. saponaria saponin. The strain Ch-B7 reduced the damage index from an average value of 4 for the control inoculated with G. graminis var. tritici to 2.7 for the $1840 \mathrm{mg} \mathrm{L}^{-1}$ concentration (32.5\% of disease reduction), which was the maximum decrease in damage achieved in this experiment (Figure 6b).

Values of the damage index obtained from the three strains were used to calculate TAI, determining a significant decrease of the disease with respect to the inoculated control, from treating pre-germinated seeds with only P. protegens, as well as by mixing them with the three saponin concentrations (1840, 4600, and $\left.9200 \mathrm{mg} \mathrm{L}^{-1}\right)$ assessed (Figure 7). Use of $9200 \mathrm{mg} \mathrm{L}^{-1}$ Q. saponaria saponin without bacteria to control take-all disease showed no significant differences in the TAI from the untreated control inoculated with the fungus.

\section{DISCUSSION}

Many saponins are considered preformed antimicrobial compounds that are part of the defense system of certain plants (Sherif et al., 2009; Augustin et al., 2011). Therefore, it is to be expected that saponins exert this type of activity on bacteria that inhabit the rhizosphere and phyllosphere of plants. Moreover, several species of plants have symbiotic associations with bacteria that contribute to their defenses against diseases and improve their physiological functions (Sivasakthi et al., 2014). In this study, the use of a crude $Q$. saponaria extracts with $8 \%$ of saponins showed a higher bactericidal effect when concentrations of $Q$. saponaria were increased. This bactericidal activity could be attributed to the lower purity of saponins of this extract, noting that $8000 \mathrm{mg} \mathrm{L}^{-1}$ saponin produced a precipitate at the bottom of micro-plate cells, possibly due to the presence of sodium benzoate preservative $\left(1 \mathrm{~g} \mathrm{~L}^{-1}\right)$ and other solids existing in the composition of this crude extract of quillaja. The pure saponin extract with $90 \%$ saponins did not exhibit this marked effect on bacterial growth, and this was why it was considered for studies on wheat roots. Pseudomonas protegens strains were slightly affected by concentrations between 0 and $8000 \mathrm{mg} \mathrm{L}^{-1}$ pure saponins, under in vitro conditions, maintaining antagonistic activity on the fungus after having been in contact with $Q$. saponaria extracts with $90 \%$ of saponins. At the same time, this low effect 
Figure 6. Damage index of wheat plants infected with Gaeumannomyces graminis var. tritici, which were treated with different Pseudomonas protegens strains combined with different concentrations of a pure Quillaja saponaria extract with 90\% saponins. Results are for strains Ca-10 (a) and Ch-B7 (b). Graphs include treatments only inoculated with bacteria (0), only treated with a concentration of $9200 \mathrm{mg} \mathrm{L}^{-1} Q$. saponaria extracts, and an untreated control (UTC), which was only inoculated with $G$. graminis var. tritici.

\section{a)}

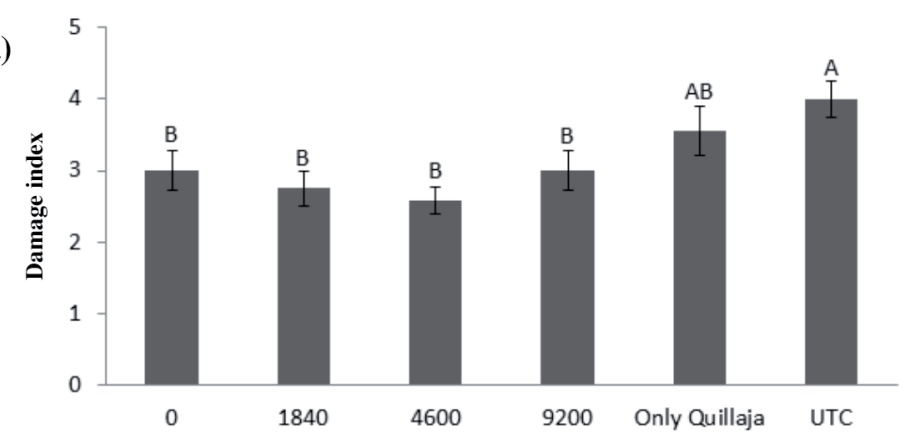

b)

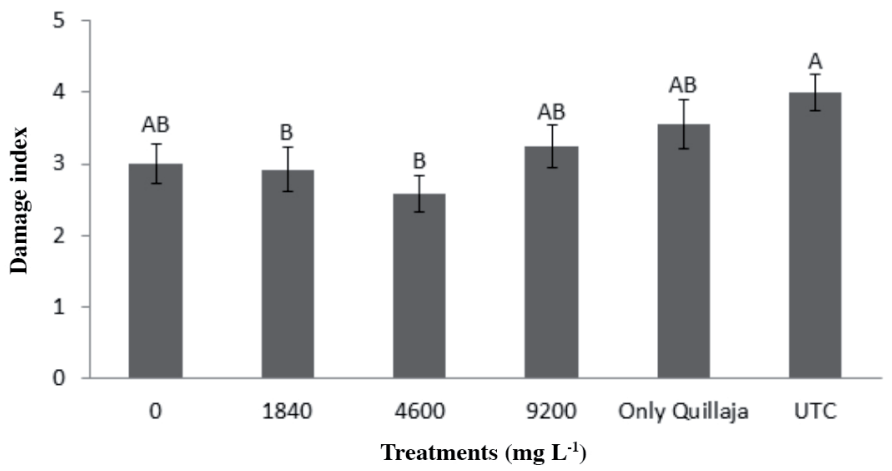

Bars represent the means of each treatment $(n=6)$. Data are expressed as mean \pm experimental error. Different letters above bars indicate significant differences between treatments by the non-parametric Kruskal-Wallis test $(\mathrm{P} \leq 0.05)$.

Figure 7. Take-all disease (TAD) damage index, caused by Gaeumannomyces graminis var. tritici in wheat plants treated with Pseudomonas protegens mixed with different concentrations of a pure Quillaja saponaria extracts with $90 \%$ saponins. Results are the average of the three strains used (Pf-5, Ch B-7, and Ca-10). Graph include treatments only inoculated with the bacteria (0), only treated with a concentration of $9200 \mathrm{mg} \mathrm{L}^{-1} Q$. saponaria extracts, and an untreated control (UTC), which was only inoculated with the fungus.

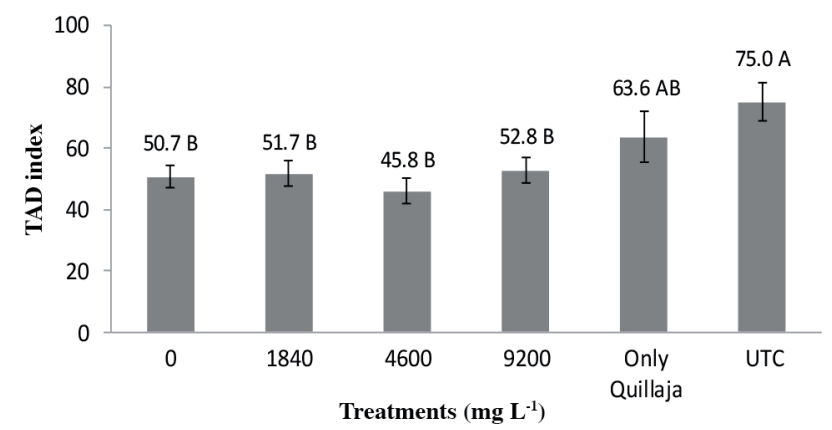

Data are expressed as mean \pm experimental error. Different letters above bars indicate significant differences between treatments by the non-parametric Kruskal-Wallis test $(\mathrm{P} \leq 0.05)$. 
on the bacterial growth of pure saponin extract was reinforced by the fact that P. protegens bacteria, cultured at 24, 48, and $72 \mathrm{~h}$ with $Q$. saponaria saponin concentrations of 1840,4600 , and $9200 \mathrm{mg} \mathrm{L}^{-1}$, did not lose their inhibitory effect on the fungus grown in the tests performed under in vitro conditions.

Antagonistic bacteria were slightly affected by $Q$. saponaria saponin concentrations between 1472 and $7360 \mathrm{mg} \mathrm{L}^{-1}$ when they were placed on the roots of wheat plants and evaluated at three different sampling times $(24,48$, and $72 \mathrm{~h})$. In general, P. protegens populations, when inoculated without saponin extracts, formed biofilm containing high bacteria concentrations on the roots of wheat. This effect was not observed when combined with different concentrations of pure extracts rich in saponins $24 \mathrm{~h}$ of culture. In the presence of saponins from $Q$. saponaria, a decrease was observed in the number of $P$. protegens bacteria, which was consistent with the number of CFU observed after $24 \mathrm{~h}$ from the inoculation with the strain Pf-5 on wheat seedling roots, containing equal concentrations of saponins ( $\left.7360 \mathrm{mg} \mathrm{L}^{-1}\right)$.

Assessment of bacterial growth in combination with diverse $Q$. saponaria saponins concentration, fluctuating between 200 and $9200 \mathrm{mg} \mathrm{L}^{-1}$, was associated with detecting a wide range of concentrations where these molecules affect $P$. protegens. Assessing high concentrations of $Q$. saponaria in combination with the antagonistic bacteria is required when a biopesticide is developed. Bacteria and saponins extract will need to be applied in concentrated form on the seed's surface before seeding, which is the more common commercial way to apply a fungicide seed treatment in order to control takeall disease. Antifungal effects of commercial $Q$. saponaria extracts against $G$. graminis var. tritici have an in vitro effect at concentrations of 50 to $500 \mathrm{mg} \mathrm{L}^{-1}$ of saponins (Apablaza et al., 2002; 2008). This concentration range is associated with hyphae deformation, mycelium thinning, and breakage of mycelia strands between fungus hyphae, as reported by Apablaza et al. (2008). This effect is attributed to the presence of triterpenic saponins, which show fungicidal activity associated with the membranolytic actions on the sterols present in the fungal cell membranes (Apablaza et al., 2002; Ribera et al., 2008; Augustin et al., 2011). Antifungal properties of saponin are attributed to aglycones present in these molecules and their ability to form a complex with sterols of the cell membranes of fungi, causing pore formation and loss of membrane integrity (Osbourn, 2003; Augustin et al., 2011). However, by placing this compound on seeds, this imply that saponins concentrations should dilute during the process of root development to protect these plant tissues. On the other hand, saponins can be lost during this process due to irrigation or rainfall. Therefore, high extract concentrations are necessary to treat wheat plants, and this was the reason for assessing between 1840 and $9200 \mathrm{mg} \mathrm{L}^{-1}$ saponins in pot experiments with wheat plants.

In vitro results with $P$. protegens suggest that crude or less-refined extracts present varied antimicrobial activities, as reported by Sen et al. (1998) and Sherif et al. (2009). This difference between the two extracts could be due to the fact that the crude quillaja extract has a lower purity level in composition ( $8 \% \mathrm{w} / \mathrm{w}$ of saponins) and contains other substances that may affect growth of Pseudomonas, such as polyphenols, salts, and simple sugars (San Martín and Briones, 2000), which may present antimicrobial activity (Negri et al., 2014).

Antibacterial properties present in saponins depend on factors such as concentration and saponins sources (Sen et al., 1998; Sherif et al., 2009; Sewlikar and D’Souza, 2017). For example, various commercial extracts that are rich in saponins have different antibacterial activity, and in some cases, have low antibacterial activity against Gram-negative bacteria such as Escherichia coli (Sen et al., 1998). This is consistent with results obtained in our study, where extracts rich in saponins from $Q$. saponaria did not reduce populations of P. protegens, a Gram-negative proteobacteria. It is possible that these saponin concentrations or aglycone remnants, which are responsible for the appearance of pores in cell membranes, may cause an increase in cell permeability, leading to improved nutrient transport in bacterial cells (Sen et al., 1998). However, an increasing growth in P. protegens was not observed in the assessed concentrations $(0,1472$, 3680 , and $7360 \mathrm{mg} \mathrm{L}^{-1}$ ) nor when each time assessed was considered separately. Nevertheless, bacterial populations of the strain Pf-5 increased after $72 \mathrm{~h}$ of incubation at 3680 and $7360 \mathrm{mg} \mathrm{L}^{-1}$ saponins from the pure Q. saponaria extract with $90 \%$ of saponins, while strain Ca-10 increased the CFU at $1472 \mathrm{mg} \mathrm{L}^{-1}$. This situation suggested that measurement times could not be enough to determine changes in bacterial populations or imply that $P$. protegens bacteria require some period of time previously to activate the mechanism associated with degradation of the sugar present in saponins molecules by the action of non-specific glycosidases (Sen et al., 1998). For the bacterial growth with different saponin concentrations, glycosidases seemed to be more active between 4600 and $9200 \mathrm{mg} \mathrm{L}^{-1}$, considering that CFU were not different from the control (King B medium) in the first $24 \mathrm{~h}$ and achieved higher bacterial populations. This situation suggests that saponin molecules were used by the bacteria (Sen et al., 1998). This $P$. protegens degrading activity on saponin molecules used 
to increase bacterial populations seems to stabilize over time, considering that nonsignificant differences were found between 24,48 , and $72 \mathrm{~h}$. However, this result could be partially explained by the high level of variability observed in the observations. Studies conducted by Sen et al. (1998) demonstrated regulatory effects of different extract concentrations from two saponin sources Q. saponaria and Yucca schidigera (Roezel ex Ortigies; Agavaceae) on bacteria, as these could linearly increase or decrease bacterial populations.

Various studies have shown the fungicidal effect of P. protegens strains that produce 2,4-DAPG (Kwak et al., 2012; Mavrodi et al., 2012), and of extracts rich in saponins from Q. saponaria (Apablaza and Moya, 2004; Apablaza et al., 2008). In this study, the combination of these two sources of Ggt control showed no clear synergism on the reduction of the disease caused by this fungus. Quillaja saponaria saponins at $0,1840,4600$, and $9200 \mathrm{mg} \mathrm{L}^{-1}$ in combination with strain Ca-10 and at 1840 and $4600 \mathrm{mg} \mathrm{L}^{-1}$ for the strain Ch-B7 of P. protegens significant controlled the disease. Similarly, under in vitro conditions, the inhibition activity of the bacteria on the fungus was maintained despite the bacteria being grown for $72 \mathrm{~h}$ in a medium with $9200 \mathrm{mg} \mathrm{L}^{-1}$ saponin derived from the pure quillaja extracts. This result discarded possible effects of the $Q$. saponaria saponins on the fungal control effect associated with the $P$. protegens bacteria. However, control of Ggt in plants treated only with bacteria or with mixtures of P. protegens and different $Q$. saponaria extract concentrations was relatively low, considering that both treatment sets averaged between $29.2 \%$ and $22.2 \%$ less root damage. Low control levels could possibly be due to the highly aggressive nature of the isolate Oso1, considering that this fungal isolate reached the maximum values of the damage index when it was inoculated in plants that did not receive treatments with the bacteria alone or in combination with the saponinic extract.

Suppressiveness of G. graminis var. tritici in certain soils is produced by the action of the different members of the microbial biomass present in these soils (Yang et al., 2011; Durán et al., 2017; Yin et al., 2017), which could be reduced by soil sterilization conducted prior to establishing the experiments. Although the specific suppression by strains that produce 2,4-DAPG tends to be higher than the rest of the microbial rhizosphere biomass, variability in the control of Ggt by beneficial bacteria is a normal phenomenon (Kwak et al., 2012). Considering the results of this study, where pure $Q$. saponaria saponin extracts showed no antagonistic effect on populations of $P$. protegens, it is not possible to attribute some kind of effect of this extract on the control properties of P. protegens on Ggt. Nevertheless, certain concentrations of saponins extracts favor bacterial growth (Sen et al., 1998); thus, it is possible that saponins extract affected the amount of antimicrobial compounds produced by $P$. protegens or affected the compound stability. For example, 2,4-DAPG has high instability in the rhizosphere of wheat plant, with an average life of $6 \mathrm{~h}$ (Kwak et al., 2012). Moreover, high soil moisture, associated with rainfall or irrigation, is one of the factors that increase the aggressiveness of Ggt in wheat plants (Paulitz, 2010; Yin et al., 2017). Irrigation performed three times a week during the experiments maintained constant moisture in the soil, which could have activated the inoculum and helped in infesting wheat plants at early stages of development. This high soil moisture could increase root damage, reducing effectiveness of triterpene compounds and antagonistic bacteria. Additionally, frequent irrigation could reduce concentrations of 2,4-DAPG and saponins, considering that bacteria and plant extracts could lixiviate or percolate bacterial cells, saponins, or antimicrobial compounds from the wheat plant roots. On the other hand, the disappearance of biofilm produced by P. protegens and observed in roots treated with Q. saponaria after $24 \mathrm{~h}$ suggests that bacteria loss could occur in early stages of inoculation, affecting its efficacy of control.

Although results obtained from the pots experiment with wheat plants were variable, some bacterial strains of $P$. protegens reduced the damage of G. graminis var. tritici when bacteria were mixed with certain concentrations of pure $Q$. saponaria saponin extract. This situation suggests that both concentrations of saponin extracts and bacterial strains used could influence Ggt control. Therefore, this research provides insight into the use of both compounds to formulate a bio-fungicide that could constitute an alternative to control this pathogenic fungus in both traditional agriculture as well as organic agriculture.

\section{CONCLUSIONS}

Pure extracts rich in triterpene saponins from Quillaja saponaria (90\% saponins) did not affect population development of the antagonistic Pseudomonas protegens bacteria, as observed for high concentrations of crude extracts with $8 \%$ saponins under in vitro conditions. Pseudomonas protegens strains producing 2,4-diacetylphloroglucinol mixed with certain concentrations of pure $Q$. saponaria saponin extracts did not affect the fungal antimicrobial activity of the bacterium, 
while they showed an initial decrease of the bacterial population after $24 \mathrm{~h}$ and increase of the populations after $72 \mathrm{~h}$ on wheat root seedlings. The initial decrease after $24 \mathrm{~h}$ was associated with biofilm formation loss in those roots treated with pure saponin extracts. Take-all disease control varied in the pots experiment with wheat plants; however, some bacterial strains of P. protegens generated a decrease in Gaeumannomyces graminis var. tritici damage when they were mixed with concentrations between 1840 and $9200 \mathrm{mg} \mathrm{L}^{-1}$ of pure $Q$. saponaria saponin extracts. These results suggest that mix of saponinic extracts with bacterial strains with antimicrobial activity on G. graminis var. tritici will be no affected and they could be considered in the formulation of an alternative bio-fungicide.

\section{ACKNOWLEDGEMENTS}

This research was funded by the FONDECYT project initiative $\mathrm{N}^{\circ} 11110105$. The National Scholarship program of CONICYT financing Masters in Agricultural Sciences at the Universidad de Concepción for first author.

\section{REFERENCES}

Ahmed, D.B., Chaieb, I., Salah, K.B., Boukamcha, H., Jannet, H.B., Mighri, Z., et al. 2012. Antibacterial and antifungal activities of Cestrum parqui saponins: possible interaction with membrane sterols. International Research Journal of Plant Science 3:001-007.

Andrade, O., Campillo, R., Peyrelongue, A., and Barrientos, L. 2011. Soils suppressive against Gaeumannomyces graminis var. tritici identified under wheat crop monoculture in southern Chile. Ciencia e Investigación Agraria 38:345-356.

Apablaza, G., Díaz, M.J., San Martin, R., y Moya, E. 2002. Control de oídio de las cucurbitáceas con saponinas presentes en extractos de quillay (Quillaja saponaria). Ciencia e Investigación Agraria 29:83-90.

Apablaza, G., y Moya, E. 2004. Evaluación in vitro del efecto de las saponinas de quillay (Quillaja saponaria Mol.) sobre el hongo Gaeumannomyces graminis var. tritici. Fitopatología 39:47.

Apablaza, G.E., Moya, E.A., and Aguilar, G. 2008. Slow-release formulations containing quillay extracts, for controlling wheat take-all disease. Patent Application Publication. Pub. Nr. US 2011/0190123 A1. Pub. Date 4 August 2011. Pub. Classification: Int. Cl. C05G 3/00, A01N 45/00, A01P 3/00, C05G 3/02. Santiago, Chile.

Augustin, J.M., Kuzina, V., Andersen, S.B., and Bak, S. 2011. Molecular activities, biosynthesis and evolution of triterpenoid saponins. Phytochemistry 72:435-457.

Donoso, S., Peña, K., Pacheco, C., Luna, G., y Aguirre A. 2011. Respuesta fisiológica y de crecimiento en plantas de Quillaja saponaria y Cryptocarya alba sometidas a restricción hídrica. Bosque 32:187-195.

Durán, P., Jorquera, M., Viscardi, S., Carrion, V., Mora, M., and Pozo, M. 2017. Screening and characterization of potentially suppressive soils against Gaeumannomyces graminis under extensive wheat cropping by Chilean indigenous communities. Frontiers in Microbiology 8:1552. https://doi.org/10.3389/fmicb.2017.01552.

Freeman, J., Ward, E., Gutteridge, J., and Baterman, L. 2005. Methods for studying population structure, including sensitivity to the fungicide silthiofam, of the cereal take-all fungus, Gaeumannomyces graminis var. tritici. Plant Pathology 54:686-698.

Kwak, Y.S., Bonsall, R.F., Okubara, P.A., Paulitz, T.C., Thomashow, L.S., and Weller, D.M. 2012. Factors impacting the activity of 2,4-diacetylphloroglucinol-producing Pseudomonas fluorescens against take-all of wheat. Soil Biology and Biochemistry 54:48-56.

Liu, B., Huang, L., Kang, Z., and Buchenauer, H. 2011. Evaluation of endophytic bacterial strains as antagonists of take-all in wheat caused by Gaeumannomyces graminis var. tritici in greenhouse and field. Journal of Pest Science 84:257-264.

Mathias-Ramwell, M., Salvo-Garrido, H., Reyes-Rebolledo, M., and Montenegro-Barriga, A. 2016. Jupiter INIA: A new oat variety with improved $\beta$-glucan and protein contents. Chilean Journal of Agricultural Research 76:401-408. doi:10.4067/ S0718-58392016000400002.

Mavrodi, O.V., Walter, N., Elateek, S., Taylor, C.G., and Okubara, P.A. 2012. Suppression of Rhizoctonia and Pythium root rot of wheat by new strains of Pseudomonas. Biological Control 62:93-102.

Moya, E.A., San Martin Gamboa, R.M., y Apablaza Hidalgo, G.E. 2010. Evaluación de un extracto de saponinas de Quillaja saponaria para el control de oídios de trigo y zapallo. Agro Sur 38:87-96.

Moya-Elizondo, E.A., Arismendi, N.L, Castro, M.P., and Doussoulin, H.A. 2015. Distribution and prevalence of crown rot pathogens affecting wheat crops in southern Chile. Chilean Journal of Agricultural Research 75:78-84 doi:10.4067/S071858392015000100011.

Moya-Elizondo, E.A., Cattan, N.C., Arismendi, N.L., and Doussoulin, H.A. 2013. Determination of 2,4-diacetylphloroglucinol (2,4-DAPG) and phenazine-producing Pseudomonas spp. in wheat crops in southern Chile. Phytopathology 103(Suppl. 2):100. 
Negri, M., Salci, T.P., Shinobu-Mesquita, C.S., Capoci, I.R.G., Svidzinski, T.I.E., and Kioshima, S. 2014. Early state research on antifungal natural products. Molecules 19(3):2925-2956.

Osbourn, A.E. 2003. Saponins in cereals. Phytochemistry 62(1):1-4.

Park, J.Y., Oh, S.A., Anderson, A.J., Neiswender, J., Kim, J.C., and Kim, Y.C. 2011. Production of the antifungal compounds phenazine and pyrrolnitrin from Pseudomonas chlororaphis O6 is differentially regulated by glucose. Applied Microbiology 52:532-537.

Paulitz, T.C. 2010. Take-All. p. 79-82. In Bockus, W., Bowden, R., Hunger, R., Morrill, W., Murray, T., and Smiley, R. (eds.) Compendium of wheat diseases and pests. $3^{\text {rd }}$ ed. The American Phytopathological Society, Saint Paul, Minnesota, USA.

Paulitz, T.C., Schroeder, K.L., and Schillinger, W.F. 2010. Soilborne pathogens of cereals in an irrigated cropping system: effects of tillage, residue management, and crop rotation. Plant Disease 94:61-68.

Ramette, A., Frapolli, M., Fischer-Le Saux, M., Gruffaz, C., Meyer, J., Défago, G., et al. 2011. Pseudomonas protegens sp. Nov., widespread plant-protecting bacteria producing the biocontrol compounds 2,4-diacetylphloroglucinol and pyoluteorin. Systematic and Applied Microbiology 34:180-188.

Ribera, A., Cotoras, M., and Zúñiga, G.E. 2008. Effect of extracts from in vitro-grown shoots of Quillaja saponaria Mol. on Botrytis cinerea Pers. World Journal of Microbiology and Biotechnology 24:1803-1811.

San Martín, R., and Briones, R. 2000. Quality control of commercial quillaja (Quillaja saponaria Molina) extracts by reverse phase HPLC. Journal of the Science of Food and Agriculture 80:2063-2068.

Schlotterbeck, T., Castillo-Ruiz, M., Cañon-Jones, H., and San Martin, R. 2015. The use of leaves from young trees of Quillaja saponaria (Molina) plantations as a new source of saponins. Economic Botany 69(3):262-272.

Sen, S., Makkar, H.P.S., Muetzel, S., and Becker, K. 1998. Effect of Quillaja saponaria saponins and Yucca schidigera plant extract on growth of Escherichia coli. Letters in Applied Microbiology 27:35-38.

Sewlikar, S., and D'Souza, D.H. 2017. Antimicrobial effects of Quillaja saponaria extract against Escherichia coli O157:H7 and the emerging non-O157 Shiga toxin-producing E. coli. Journal of Food Science 82:1171-1177.

Sherif, M.H., Byrd, J.A., Cartwright, A.L., and Bailey, C.A. 2009. Hemolytic and antimicrobial activities differ among saponinrich extracts from guar, quillaja, yucca, and soybean. Applied Biochemistry and Biotechnology 162:1008-1017.

Sivasakthi, S., Usharani, G., and Saranraj, P. 2014. Biocontrol potentiality of plant growth promoting bacteria (PGPR) Pseudomonas fluorecens and Bacillus subtilis: A review. African Journal of Agricultural Research 9:1265-1277.

Soil Survey Staff. 2014. Claves para la taxonomía de suelos. $12^{\mathrm{a}}$ ed. 410 p. USDA, Washington, D.C., USA.

Vazvani, M., Dashti, H., Saberi, R., and Bihamta, M. 2017. Screening bread wheat germplasm for resistance to take-all disease (Gaeumannomyces graminis var. tritici) in greenhouse conditions. Journal of Agricultural Science and Technology 19:1-12.

Vera, C., Madariaga, R., y Moya-Elizondo, E. 2014. Uso de fluquinconazole como tratamiento a la semilla para el control de mal del pie (Gaeumannomyces graminis var. tritici) en trigo. Chilean Journal of Agricultural and Animal Sciences 30:159-169.

Yang, M., Mavrodi, D., Mavrodi, O., Bonsall, R., Parejko, J., Paulitz, T., et al. 2011. Biological control of take-all by fluorescents Pseudomonas spp. from Chinese wheat fields. Phytopathology 101:1481-1491.

Yang, M., Mavrodi, D., Mavrodi, O., Thomashow, L., and Weller, D. 2017. Construction of a recombinant strain of Pseudomonas fluorescens producing both phenazine-1-carboxylic acid and cyclic lipopeptide for the biocontrol of take-all disease of wheat. European Journal of Plant Pathology 149:683-694. doi:10.1007/s10658-017-1217-6.

Yang, M., Wen, S., Mavrodi, D., Mavrodi, O., Wettstein, D., Thomashow, L., et al. 2014. Biological control of wheat root disease by the CLP-producing strain Pseudomonas fluorescens HC1-07. Phytopathology 104:248-256.

Yin, C., Mueth, N., Hulbert, S., Schlatter, D., Paulitz, T., Schroeder, K., et al. 2017. Bacterial communities on wheat grown under long-term conventional tillage and no till in the Pacific Northwest of the United States. Phytobiomes Journal 1:83-90. https://doi.org/10.1094/PBIOMES-09-16-0008-R.

Zhang, D., Guo, X., Wang, T., and Zhu, B. 2017. Novel screening strategy reveals a potent Bacillus antagonist capable of mitigating wheat take-all disease caused by Gaeumannomyces graminis var. tritici. Letter in Applied Microbiology 65:512-519. 